\title{
TANULMÁNYOK
}

\section{Faludi Tamás \\ Az ostorcsapás-effektus mérése, illetve hatásának csökkentésére alkalmazható menedzsment megoldások}

\begin{abstract}
$A z$ ostorcsapás-effektus eliminálása vagy legalább hatásának csökkentése a XXI. századi ellátásilánc-menedzsment egyik nagy kihívását jelenti. A kereslet dinamikus változása a vállalatokat arra készteti, hogy bizonyos mennyiségü készletet halmozzanak fel, hogy minden esetben ki tudják elégíteni a felmerült igényeket. Amennyiben ez pontatlan elörejelzéseken alapul, begyürüzik az egész láncra, és így a piactól visszafelé haladva egyre nagyobb kilengések észlelhetök a keresleti elörejelzésekben, ezáltal pedig a lánctagok készletmennyiségében is, ami hatalmas költségnövekedéssel és a müködési hatékonyság romlásával jár. A tanulmány bemutatja az ostorcsapás-effektus mérésének módszerét, mely segithet felismerni azt a tényt, hogy a láncon belüli információáramlás nem hatékony, az információmegosztás pedig ezáltal elégtelen szintü. Ennek javitására bemutatásra kerülnek az ostorcsapás-effektus hatásainak csökkentésére alkalmazható különbözö menedzsment eszközök. Egy számszerü példa illusztrálja az ostorcsapáseffektust, illetve azt, hogy milyen hatással vannak az effektusra a javasolt javítási mechanizmusok.
\end{abstract}

Kulcsszavak: ellátásilánc-menedzsment, ellátásilánc-koordináció, ostorcsapás-effektus, keresletmenedzsment, szerzödéstípusok, stratégia

JEL-kód: D21, L11, M10

https://doi.org/10.32976/stratfuz.2021.1

\section{Bevezetés}

A XX. század második felében az üzleti élet változásnak indult. A stratégiai menedzsment fejlődése, melynek hatására ez a terület egyre nagyobb teret kapott a vállalkozások müködésében, segítségül szolgált, hogy kisebb-nagyobb mértékben képesek legyenek a változó környezethez alkalmazkodni. Ennek a változásnak az egyik legnagyobb mozgatórugója a globalizáció volt. A szabad kereskedelem, a határok kereskedelmi értelemben vett megszünése lehetővé tette, hogy a vállalatok nemzetközi színtérre lépjenek. Nem csak leányvállalatok jöttek létre, hanem bizonyos folyamatokat ki is szerveztek a cégek más országokban, ahol esetlegesen kedvezöbben voltak a müködési feltételek. Ezek hatására megváltoztak a vállalatok partnerviszonyai is - sok cég már hosszabb távra kezdett el gondolkodni egy-egy partnerrel és így megjelentek a különböző stratégiai szövetségek is.

A változások nagyban hozzájárultak az ellátási láncok és az ellátásilánc-menedzsment fejlődéséhez és fontosságának felértékelődéséhez. A tradicionális láncok bővülésnek indultak, egyre több lánctag csatlakozott a láncokhoz. A vállalatok nemzetközi szinten történő terjeszkedése megkövetelte, hogy egyre több beszállítóval dolgozzanak, hiszen helyi szinten kellett megoldani az áruellátást, ez pedig azt jelentette, hogy a különböző országok és azok vonzáskörzetéből szerződtették le a beszállítókat a vállalatok. A láncok ezáltal egyre hosszabbak, szélesebbek lettek, mely további problémákat vonzott maga után. Ugyanis ennyi lánctaggal rendelkező ellátási láncon belül nagyon nehéz a megfelelő információáramlás biztosítása, vagyis nagy kihívást jelent az ellátási lánc koordinációja. Az információáramlás elengedhetetlen feltétele az eredményes és 
hatékony müködésnek, viszont az ellátási láncok növekedési jelensége pont ezt a tényezöt befolyásolja - méghozzá negatívan. Az ellátásilánc-menedzsment és így az ellátásilánckoordináció egyik legnagyobb és legfontosabb küldetése az elégtelen információáramlás miatt kialakult ostorcsapás-effektus hatásainak minimalizálása lett.

\section{Az ostorcsapás-effektus értelmezése}

Az ellátásilánc-koordináció célja, hogy az ellátási lánc tagjai és így a teljes lánc egy kollektív célkitűzés érdekében a megfelelő kooperáció segítségével, az emberek és folyamatok közötti interakciók menedzselése révén hatékonyan és eredményesen tudjon müködni (Gupta-Weerawat 2006, Kaipia 2007). Tehát a koordináció hiánya bizonytalanságot generálhat a láncon belül, mely az erő-egyensúly felborulását, az egyéni érdekek priorizálását, a kooperációtól történő eltávolodást okozhatja. Ezek a tényezők pedig potenciális veszteségforrások, melyek a működési költségek megnövekedését is okozhatják.

A nem megfelelő információáramlás okozta gyengébb együttmüködés miatt a lánctagok pontatlan, illetve nem elegendő információkkal rendelkeznek a következő lánctag valós keresletéröl. Így, mivel a vállalatok racionálisan viselkednek, egy előrejelzésen alapuló tételnagyságot állapítanak meg az adott rendeléshez. Ez az elörejelzés általában pontatlan, egyes esetekben szándékosan abból a célból, hogy bizonyos mennyiségü készletet felhalmozzon a vállalat, hogy bármilyen fogyasztói igényváltozásra azonnal tudjon reagálni. Ez a fajta viselkedésforma a többi tagnál is megjelenhet. A láncon adott pozícióban levő vállalat a közvetlen partneréhez fogja viszonyítani saját rendelését, így ha azt tapasztalja, hogy a partner nagyobb mennyiséget vásárol vagy rendel, akkor természetes módon ez a cég is nagyobb mennyiséget fog beszerezni. Ez a jelenség kiterjedhet az egész láncra. Ilyen esetben az ellátási láncon a végső fogyasztótól visszafelé haladva egyre nagyobb kilengések tapasztalhatók a készletmennyiségekben, illetve a keresletben (Szegedi 2017). Ekkor beszélünk ostorcsapáseffektusról (1 ábra).

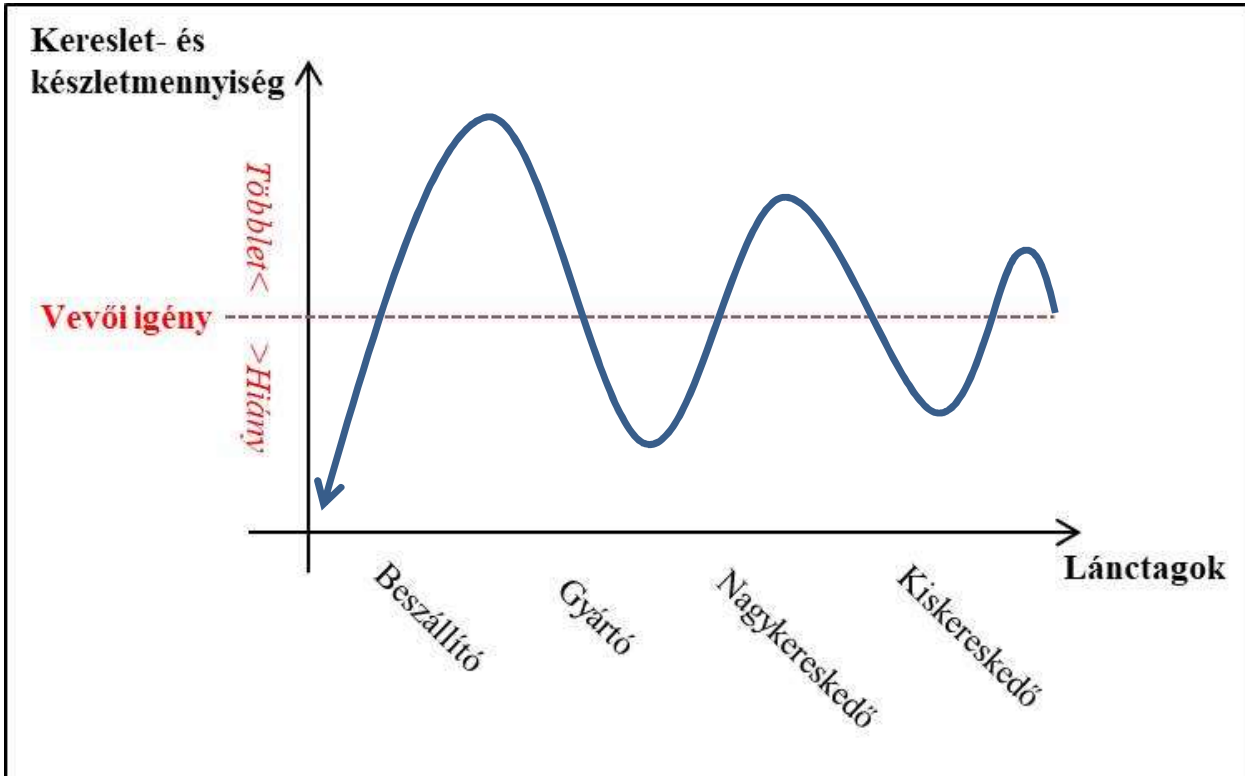

1.ábra: Ostorcsapás-effektus egy hagyományos ellátási láncon

Figure 1: Whiplash effect on a conventional supply chain

Forrás: saját szerkesztés Szegedi 2017 alapján 
Az ábrán látható vevői igény a végső fogyasztó szükségleteire vonatkozik, annak egy ideális esetét reprezentálja, vagyis azt a helyzetet vázolja, amikor a vevői igény nem változik, hanem konstans. Látható, hogy ehhez a fogyasztói igény szinthez képest jóval nagyobb eltérések vannak az ellátási láncon visszafelé haladva. A fogyasztóhoz legközelebb álló lánctag - jelen ábra esetében a kiskereskedő - fogja a legpontosabban ismerni a piaci igényeket. Ha ezt az információt nem továbbítja, szándékosan fals vagy torz értékeket közöl a keresleti igényre vonatkozóan, vagy csak egyszerüen visszatart néhány releváns információt, mely segítené az őt kiszolgáló másik lánctag előrejelzéseit pontosabbá tenni, akkor ez a tag is a valós igényektől eltérő mennyiséget fog rendelni. Ekkor felhalmozódhat az árukészlet, és ez a készletezési költségek növekedését okozhatja. Ezután a racionális gondolkodást követve kevesebb árut fog rendelni a cég - vagy akár egyáltalán nem is rendel -, amire viszont, ha egy radikálisan megnövekedett vevői igény lesz a válasz, készlethiány fog felmerülni. A gyors hiány pótlása szintén költséggel jár. A legfőbb probléma, hogy ez begyürüzik az egész ellátási láncba és ekkor egyre nagyobb differenciák jelentkeznek a lánctagoknál. Ez fogja az ostorcsapásszerü tendenciát okozni az 1. ábrán.

Az ostorcsapás-effektus tehát elsősorban az elégtelen információáramláson alapul, és több súlyos problémát idéz elö. A szakirodalom alapján ez főként a vállalatok racionális viselkedésének tudható be, azonban ezen kívül számos más ok is közrejátszik az effektus kialakulásához. Nem elhanyagolható tényező magának a láncnak a müködése során felmerülő problémák. Az emberi tényező, mint hibafaktor, ebben az esetben is erősítheti az effektust a különböző adatbeviteli hibáknak köszönhetően. A multinacionális láncok miatt egyes országok más és más mértékegységeket használnak, ami szintén hibalehetőséget foglal magába, de ugyanebben az esetben gondolhatunk a különböző deviza átváltásokban rejlö problémaforrásokra is. Ezen túlmenően jellemző a mai üzleti életre, hogy a cégek kiárusítási akciókkal szándékosan áringadozást kreálnak bizonyos termékek vagy szolgáltatások esetében. Ekkor hirtelen keresletnövekedés tapasztalható, hiszen még áremelkedés előtt szeretnék a vevők kedvező áron beszerezni az adott terméket vagy igénybe venni az adott szolgáltatást. Ez a folyamat szintén a készletek megnövekedését fogja eredményezni (Constantino et al. 2013).

Ha egy láncon belül kimutatható az ostorcsapás-effektus, akkor elsösorban az együttmüködés hiányára vagy annak nem megfelelő szintjére kell gyanakodni. Érdemes számszerüsíteni a hatást, így meghatározható maga a jelenség jelenléte, illetve annak mértéke is. A tanulmány következö fejezeteiben bemutatom, hogyan lehet mérni az ostorcsapás-effektust, valamint milyen menedzsment eszközök állnak a cégek rendelkezésére, hogy az effektus hatásait csökkenteni lehessen.

\section{Az ostorcsapás-effektus mérése egy számszerű példával illusztrálva}

Az egyenetlen erőforrás-kihasználás hosszú távon nagyon költséges a vállalatok számára. Ezért érdemes folyamatosan ellenőrizni, hogy a lánctagok igényei mennyire igazodnak a valós vevői igényekhez - legyen az egy adott lánctag vevője vagy pedig az adott piac végső fogyasztója.

Mivel alapvetően a kereslet-, illetve a készletingadozás segítségével azonosítható a jelenség, ezért az alkalmazandó mutatószám a relatív szórást veszi alapul, vagyis az átlag és tapasztalati szórás hányadosát. Jelen esetben ez az adott periódusban az adott tag rendelési tételeinek relatív szórását, valamint az adott taghoz viszonyított előző tag rendelésének - vagyis igényeinek - a relatív szórását fogja jelenteni. A két relatív szórás hányadosa fogja megadni az ostorcsapáseffektus méröszámát, vagyis a Bullwhip Ratio-t (Chen et al. 2000).

Adott egy ellátási lánc piachoz közeli része. Itt található sorban a végső fogyasztó, a kiskereskedő, nagykereskedő és gyártó. Az ostorcsapás-effektus mérésére és a kapott eredmények értékelésére ezt az egyszerü láncot fogom alkalmazni a továbbiakban (2. ábra). 


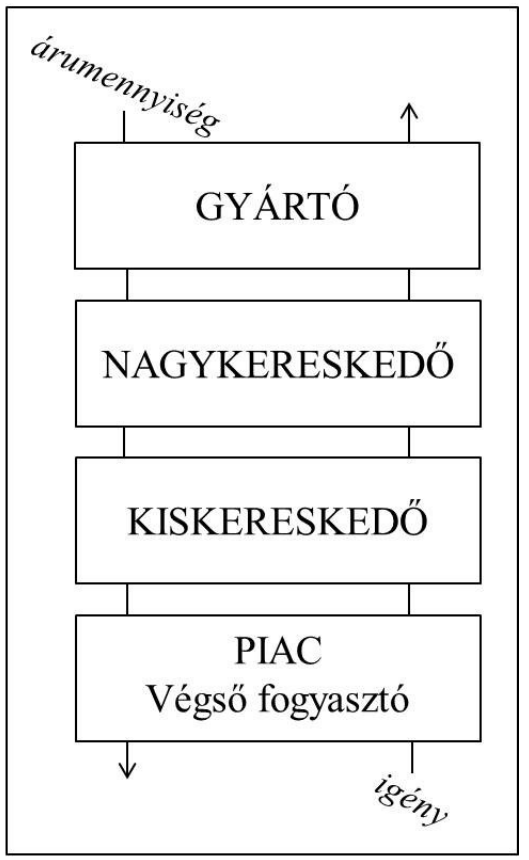

\section{2. ábra: A számításhoz alkalmazott ellátási lánc modell}

Figure 2: Supply chain model used for the calculation

Forrás: saját szerkesztés

A Bullwhip Ratio-t két részre bontom a pontosabb eredmény érdekében. Egyrészt megvizsgálom, hogy a végső fogyasztói igényekhez mérten hogyan alakulnak a keresleti- és készletingadozások az egyes lánctagoknál. Másrészt górcső alá veszem, hogy az egyes lánctagok az egymáshoz viszonyított igényeikhez képest hogyan alkalmazkodnak. Ezzel a vizsgálattal két dolog is beazonosítható: van-e ostorcsapás-effektus az ellátási láncon, illetve hogy az egyes tagok a közvetlen partnerük igényeit mennyire ismerik, és ehhez mennyire alkalmazkodnak a rendelési tételnagyság alapján.

A relatív szórás segítségével számítható ki a Bullwhip Ratio, melyhez ki kell számítani a rendelések és igények átlagát, szórását és relatív szórását(1. táblázat).

1.táblázat: A példában alkalmazott jelölések

Table 1: Symbols used in the example

\begin{tabular}{|l|r|}
\hline \multicolumn{1}{|c|}{ Megnevezés } & \multicolumn{1}{|c|}{ Jelölés } \\
\hline átlag & $\bar{x}$ \\
szórás & $S_{x}$ \\
relatív szórás (adott lánctag rendelése) & $\mathrm{O}\left[{ }^{S_{x}} / \bar{x}\right]$ \\
relatív szórás (végső fogyasztó igénye) & $\mathrm{D}\left[{ }^{S_{x}} / \bar{x}\right]$ \\
relatív szórás (előző lánctag igénye) & $\mathrm{D}^{-1}\left[{ }^{S_{x}} / \bar{x}\right]$ \\
Bullwhip Ratio - teljes láncra vonatkozóan & $B W R^{0}$ \\
Bullwhip Ratio - előző lánctagra vonatkozóan & $B W R^{-1}$ \\
\hline
\end{tabular}

Forrás: saját szerkesztés 
Az 1. táblázat által bemutatott értékek segítségével megalkotható az (1) és (2) képlet, a két Bullwhip Ratio, vagy röviden a BWR mutatószámok.

$$
\begin{aligned}
B W R^{0} & =\frac{\mathrm{O}\left[S_{x} / \bar{x}\right]}{\mathrm{D}\left[S_{x} / \bar{x}\right]} \\
B W R^{-1} & =\frac{\mathrm{O}\left[{ }^{S_{x}} / \bar{x}\right]}{\mathrm{D}^{-1}\left[{ }^{S_{x}} / \bar{x}\right]}
\end{aligned}
$$

A vizsgálathoz meg kell határozni, hogy a tagok milyen készletpolitikát követnek, vagyis milyen készletezési modellt alkalmaznak, hiszen ez alapvetően befolyásolni fogja a rendelés periodikusságát, illetve a rendelés mennyiségét is.

A láncra jellemző a racionális viselkedés, tehát az alkalmazott készletezési politika szerint a lánctagok igyekeznek bizonyos mennyiségü biztonsági készletet felhalmozni az esetleges igényváltozások kielégítése céljából. Így a tagok az aktuális igény negyedszeresén próbálják a raktárkészletüket fenntartani, vagyis az igény negyedszeresén tartják az adott periódus zárókészletét, hogy mindenképpen legyen a következő periódusra némi tartalék.

A példa négy rendelési periódust vesz figyelembe. Az első periódus nyitókészletei a vevői igénynek a másfélszeresével egyezik meg, ugyanis feltételezem, hogy az információáramlás hiányos, így nincsenek meg azok az információk, melyek alapján pontosabban meg lehet határozni az igényeket. A leírtak alapján a 2. táblázat mutatja meg az egyes tagok periódusonkénti nyitó-, és zárókészletét, valamint a leadott rendelési mennyiségeket.

\section{2. táblázat: Az adott ellátási lánc tagjainak készletgazdálkodása (ezer db)}

\begin{tabular}{|c|c|c|c|c|c|c|c|c|c|c|}
\hline \multirow[b]{2}{*}{\begin{tabular}{c|} 
\\
$\vdots$ \\
$\vdots$ \\
$\vdots$ \\
$\vdots$ \\
$\vdots$ \\
2
\end{tabular}} & \multirow[b]{2}{*}{ 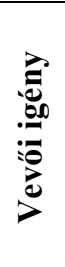 } & \multicolumn{3}{|c|}{ Kiskereskedő } & \multicolumn{3}{|c|}{ Nagykereskedő } & \multicolumn{3}{|c|}{ Gyártó } \\
\hline & & 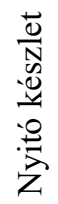 & 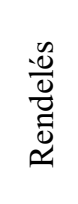 & 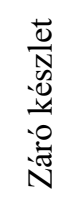 & 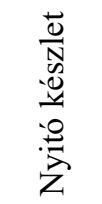 & $\begin{array}{l}\frac{\infty}{0} \\
\frac{0}{0} \\
\frac{0}{0} \\
\simeq\end{array}$ & 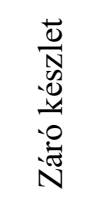 & 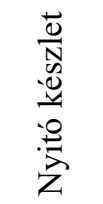 & $\frac{\frac{n}{0}}{\frac{0}{0}}$ & 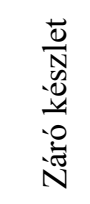 \\
\hline 1 & 8 & 12 & 6 & 10 & 12 & 3 & 7,5 & 12 & 2,25 & 3,75 \\
\hline 2 & 12 & 10 & 17 & 15 & 7,5 & 30,75 & 21,25 & 3,75 & 65,44 & 38,44 \\
\hline 3 & 16 & 15 & 21 & 20 & 21,25 & 26 & 26,25 & 38,44 & 20,06 & 32,5 \\
\hline 4 & 18 & 20 & 20,5 & 22,5 & 26,25 & 19,88 & 25,63 & 32,5 & 12,23 & 24,85 \\
\hline
\end{tabular}

Table 2: Inventory management of members of a given supply chain

Forrás: saját szerkesztés

A 2. táblázatban felvázolt értékek segítségével kiszámolható a BWR mutatókhoz szükséges átlagok és szórások. Ezen értékeket, illetve magát a BWR mutatókat a 3. táblázat tartalmazza. 
3. táblázat: Az ostorcsapás-effektus mérésére alkalmazott mutatószámok Table 3: Indicators used to measure the whiplash effect

\begin{tabular}{|c|c|c|c|c|}
\hline & Vevői igény & Kiskereskedő & Nagykereskedő & Gyártó \\
\hline$\overline{\boldsymbol{x}}$ & 13,5 & 16,13 & 19,91 & 24,99 \\
\hline $\boldsymbol{s}_{\boldsymbol{x}}$ & 4,43 & 6,98 & 12,12 & 27,93 \\
\hline $\boldsymbol{s}_{\boldsymbol{x}} / \overline{\boldsymbol{x}}$ & 0,33 & 0,43 & 0,61 & 1,12 \\
\hline $\boldsymbol{B} \boldsymbol{W} \boldsymbol{R}^{\mathbf{0}}$ & - & $\mathbf{1 , 3 0}$ & $\mathbf{1 , 8 5}$ & $\mathbf{3 , 3 9}$ \\
\hline $\boldsymbol{B W}^{\mathbf{- 1}}$ & - & $\mathbf{1 , 3 0}$ & $\mathbf{1 , 4 2}$ & $\mathbf{1 , 8 4}$ \\
\hline
\end{tabular}

Forrás: saját szerkesztés

A 3. táblázatban vázolt eredmények alapján megállapítható, hogy ezen az ellátási láncon is megmutatkozik az ostorcsapás-effektus. A $\mathrm{BWR}^{0}$ mutató monoton növekvő tendenciát mutat, ahogy a láncon visszafelé haladunk, ami azt jelenti, hogy az igények egyre jobban eltérnek a valós piaci igényektől. A BWR ${ }^{-1}$ mutatószám is monoton növekedése miatt megállapítható, hogy a lánctagok egymás igényeit is kevésbé pontosan ismerik. Egyre nagyobb a különbség a lánc eleje felé haladva a partnerek között, vagyis egyre pontatlanabbak a tagok információi a közvetlen partner igényeiről. A különbségeket jól reprezentálja a 3. ábra.

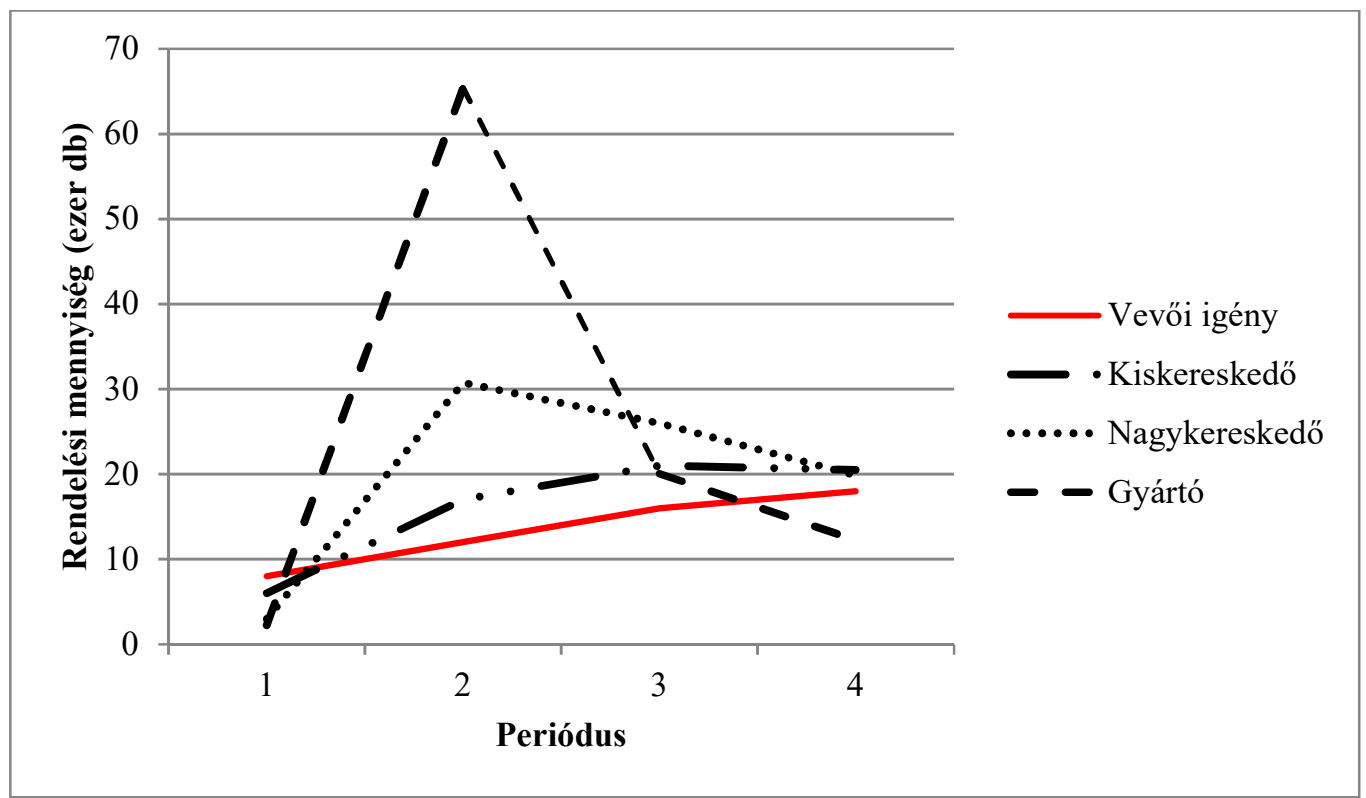

3. ábra: Az eredmények grafikus ábrázolása

Figure 3: Graphical representation of the results

Forrás: saját szerkesztés

A vevői igényekhez képest a láncon visszafelé haladva egyre nagyobb kilengések láthatók a rendelési mennyiség vonatkozásában, ami tulajdonképpen az ostorcsapás-effektus jelenlétét mutatja meg. Ez alapján a legkisebb veszteséget - vagyis a legkisebb költségtöbbletet - a kiskereskedő fogja viselni, hiszen az rendelései közel járnak a valós piaci igényekhez, így kevés készletet kell felhalmoznia és a biztonsági készlet is alacsony szinten tartható, mely szintén 
csökkenti a készletezési költségeket. Az utána lévő tagok rendelései viszont messze állnak az optimális rendelési tételnagyságtól, mely készletek felhalmozását fogja eredményezni, föként a második periódusban.

Az ábrán látható, hogy a gyártó, aki a legtávolabb áll a piacon található végső fogyasztótól, előnytelen helyzetben van, hiszen nincs pontos információja a piaci igények változásáról, sem pedig a közvetlenül mellette álló lánctag szükségleteiről. Így nagyon pontatlanok az erre vonatkozó előrejelzései is, ezért látható, hogy minél nagyobb készletmennyiséget igyekszik felhalmozni, majd fokozatosan csökkenteni a rendelését, hogy a készletmennyiség már csökkenő ütemben növekedjen.

Az ostorcsapás-effektus okozta költségek növekedése csökkenti a hatékony és eredményes működést az ellátási lánc tagjainál. Ezért a menedzsment céljai közé kell, hogy tartozzon az effektus hatásának csökkentése. A következő fejezet potenciálisan jó megoldásokat javasol menedzsmenti szinten az ostorcsapás-effektus csökkentése érdekében.

\section{Az ostorcsapás-effektus hatásának csökkentésére alkalmazható megoldások}

Alapvetően az információáramlás és legfőképpen az információ megosztása lenne a kulcsmomentum az ostorcsapás-effektus hatásának csökkentésében. A keresleti információk megosztása nagyban hozzájárulna a közvetlen partnerek igényeinek elörejelzésében is. Ehhez azonban szükséges egy bizonyos szintü bizalom a lánctagok részéröl.

A stratégiai szövetségek kialakítása segítheti ezt a folyamatot. Tehát javasolt a stratégiai gondolkodásmód bevezetése az ostorcsapás-effektus hatásának csökkentésére. Ehhez viszont szükség van arra a rendszerszemléletre, melynek segítségével az egész lánc egy közös cél elérése érdekében müködő folyamatként van definiálva. Így a szövetség kialakítása előtt érdemes elsajátítani az ellátási lánc koncepcióját, mely tulajdonképpen egy menedzsmenti filozófiát jelent. Ezzel láthatóvá válik a vállalat számára a termékek-, szolgáltatások-, információk áramlása, egyértelmüvé válnak a láncon belüli szerepek, és nagyban hozzájárul a partneri viszonyok kialakításához (Mentzer et al. 2001). Ezek után alkalmazható a stratégiai tervezés, mely nemcsak a vállalatok közötti kapcsolatot és így az ellátási lánc integrációjához az együttmüködés magasabb szintre történő emelése révén járul hozzá, hanem a vállalat működési stratégiájának kialakítását is elősegíti. Az ellátási láncon belül alkalmazható vállalati stratégiák közül jelen esetben a „húzó” (pull) stratégia, a „nyomó” és „húzó” (push és pull) stratégia összevonása, valamint a lean stratégia segíthet az effektus háttérbe szorításában. „Húzó” stratégia esetében a vállalat termelését a már felmerült piaci igények fogják irányítani, így pontosan meghatározható a vevő igénye és csak a szükségleteknek megfelelő mennyiséget szükséges legyártani. Így a láncon belül minden egyes tag csak ennek a mennyiségnek megfelelö alkatrészeket, alapanyagot, félkész- és készterméket fog rendelni, gyártani és értékesíteni. Kevert stratégia esetén készletre gyártanak, majd a felmerült igényeknek megfelelően a vevő részére továbbítják az árut. Ebben az esetben tehát tulajdonképpen a gyártási folyamatokat a „nyomó” stratégia irányítja, míg a készterméket forgalmazó vállalatok a „húzó”-elv szerint fognak müködni. A lean stratégia viszont tovább lép a keresleti igények azonosításán és célja a nem értékteremtö folyamatok kiküszöbölése a láncból. A lean stratégiát ezért karcsúsításnak is nevezi a szakirodalom (Szegedi 2017).

A stratégiák alkalmazása láthatóan egy központi kérdésre összpontosít: a kereslet minél pontosabban történő előrejelzésére. Ezért javasolt a vállalati menedzsment körébe beépíteni a keresletmenedzsmentet is. A keresletmenedzsment lényege, hogy azonosítani lehessen azokat a múltbéli hatásokat, melyek a keresletet befolyásolták, hiszen ezek segítségével lehet majd előrejelzést készíteni, illetve akár befolyásolni azt a vállalat céljainak megfelelően. A keresleti terv különböző trendszámításokon alapul és több menedzsment terület - mint például a logisztika, a marketing - összehangolt munkájának eredménye (Nagy-Bódi-Schubert 2014). Az elörejelzések pontosságát befolyásolhatja a partnerkapcsolat minősége is. Ezzel a gondolattal pedig visszacsatolhatunk a fejezet elejére, bizonyítva így, hogy mennyire fontos az információ 
megosztása. Az ellátási láncon belül erre külön eszközt alkalmaznak, melynek neve CPFR. A CPFR a közös értékesítéstervezésre, az egyes lánctagok elörejelzésének összehangolására és az ezekre vonatkozó adatok megosztására koncentráló folyamat. Így többek között az ellátási lánc koordinációját is elősegíti a folyamat, viszont ehhez egy magas szintű kooperáció, együttműködés, bizalom szükséges a vállalatok részéről (Hill et al. 2018). Ezt a folyamatot elősegítő eszköz, mely a hatékony kooperációt is megalapozhatja a CRM, vagyis az ügyfélkapcsolatok menedzsmentje. Segítségével magas szintü együttműködés alakítható ki a vállalat legfontosabb vevőivel, partnereivel (Nagy-Bódi-Schubert 2014).

$\mathrm{Az}$ eddig említett tényezők, mint az információmegosztási hajlandóság, a bizalom a koordináció puha tényezői közé tartoznak, azonban érdemes a kemény tényezők csoportjával is foglalkozni (Szegedi 2017). A kemény tényezők közé tartozik az informatikai rendszerek alkalmazása, ahol egyes kutatók szerint érdemes lehet mesterséges intelligenciát is alkalmazni, amennyiben ezt az IT rendszer lehetővé teszi. Ezzel egy sokkal pontosabb előrejelzési rendszer alakítható ki (Prakash - Pandey 2014). Másik fontos és a szakirodalom által preferált kemény koordinációs tényező a szerződéstípusok. A szerződések kontrollálni és irányítani képesek a vállalatok közötti együttműködést, meghatározzák, hogy milyen arányban szükséges megosztani a vállalatoknak a különböző kockázatokat, költségeket, nyereségeket és hasznokat (Coltman et al. 2009). A szakirodalom számos szerződést különböztet meg, melyek alkalmazása nagyban függ a vállalati partnerkapcsolat jellegétől. Így minél nagyobb az együttműködés a felek között, annál kedvezőbb konstrukciójú szerződést lehet választani. Ezért is lehet fontos a stratégiai szövetség megléte, így a partnerek számára kölcsönösen előnyös szerződéstípus választható vagy akár egy egyedi szerződés is kialakítható a különböző típusokból. Az üzleti életben találhatók már jól bevált konstrukciók, mint például a korábbi DVD piacon tevékenykedő filmkölcsönzők által alkalmazott árbevétel-megosztási szerződés (Altug-Ryzin 2014), vagy a take-it-or-leave-it típusú szerződés gázpiacokon történő alkalmazása (Polo-Scarpa 2013). A szerződések a koordináció javításával az ellátási lánc integrációját is elősegítik.

Összegezve tehát a következő menedzsment eszközök alkalmazása javasolt az ostorcsapáseffektus hatásának csökkentése érdekében:

- ellátási lánc koncepció implementálása és integráció;

- $\quad$ stratégiai menedzsment tervezési eszközei;

- lean menedzsment eszközök;

- keresletmenedzsment;

- integrált vállalatirányítási rendszerek;

- $\quad$ kapcsolatspecifikus szerződéstípusok alkalmazása.

A számszerü példa is bizonyította, hogy ha a tagok nincsenek elegendő keresleti információval ellátva, akkor a rendelési mennyiségek nem fognak illeszkedni a valós igényekhez, mely több probléma forrása is lehet. Ezért érdemes a menedzsment által kínált eszközök együttes alkalmazása, mely minimalizálhatja, sőt akár teljesen kizárhatja az ostorcsapás-effektust és az általa okozott negatív hatásokat. A hiányos információáramlás kiküszöbölhető a megfelelő partnerkapcsolattal. Ha ezt a kapcsolatmenedzsmentet megtámogatja a vállalati vezetés egy keresletmenedzsmenttel is, akkor tulajdonképpen az előrejelzési hibák nullára redukálhatók. A kapcsolatmenedzsment segít, hogy a bizalom kialakuljon a partnerek között, ezáltal erősítve a kooperatív kapcsolatot, mely az információmegosztás és az információáramlás alapja. Ekkor a vállalat rendelkezni fog azokkal az információkkal, melyek szükségesek egy pontos keresleti elörejelzéshez, melyet a keresletmenedzsment által kínált eszközök szintén támogatni fognak a még pontosabb eredmény elérése érdekében. A kapcsolat kiépítése után a megfelelő szerződéstípus kiválasztásával és alkalmazásával a költségek és nyereségek is a vállalatok szándékai szerint lesznek megosztva. 
Az összehasonlítás szemléltetése miatt a tanulmányban szereplő számszerű példán elvégeztem egy újabb vizsgálatot. A példa esetében elsődlegesen a készletezési politikán kell változtatni, vagyis más készletezési modell alkalmazása javasolt. Ha az ellátási lánc tagjai pontosabb keresleti információkkal rendelkeznek az alkalmazott menedzsment eszközöknek köszönhetően, akkor alkalmazhatóvá válik a puffer készlet. A puffer készlet egy racionalizált biztonsági készletet jelent. Alkalmazása akkor eredményes, hogy ha a keresleti információk alapján viszonylag pontos előrejelzések készíthetők. Ugyanakkor felkészíti a vállalatot az igények trendeken alapuló, de mégis random változására, mely így védelmet nyújt a készlethiány ellen. Ennek ellenére csökkenti a készletezési költségeket is, mivel csak egy adott mennyiségű készletet tart zárókészleten.

A példában a puffer készlet az igények szórásainak kétszerese lesz. A lánctagok célja így tehát az előző lánctagnál felmerülő igények szórásának kétszeresén tartani a zárókészletet.

A pontosabb információknak köszönhetően a nyitókészletek az első periódusban jelen esetben csupán csak az előző lánctag igényeit veszik figyelembe, azok negyedszeresei lesznek ellentétben az előző esettel, ahol ugyanez az érték a vevői igény másfélszerese volt.

Az új adatokkal történő számítások eredményeit, valamint a BWR mutatószámok értékeit mutatja a 4. táblázat.

4. táblázat: Eredmények puffer készlet alkalmazása esetén

Table 4: Results when using a buffer set

\begin{tabular}{|c|c|c|c|c|c|c|c|c|c|c|}
\hline \multirow[b]{2}{*}{\begin{tabular}{c|c}
3 \\
$\vdots$ \\
$:$ \\
$\vdots$ \\
$\vdots$ \\
2
\end{tabular}} & \multirow[b]{2}{*}{ 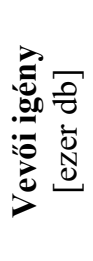 } & \multicolumn{3}{|c|}{ Kiskereskedő } & \multicolumn{3}{|c|}{ Nagykereskedő } & \multicolumn{3}{|c|}{ Gyártó } \\
\hline & & 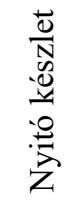 & $\frac{\sqrt[0]{0}}{\frac{0}{0}}$ & 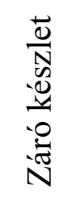 & 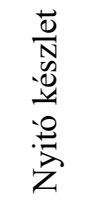 & $\frac{\mathscr{0}}{\frac{0}{0}}$ & 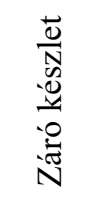 & 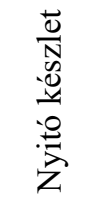 & 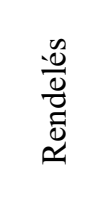 & 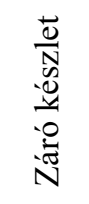 \\
\hline 1 & 8 & 10 & 6,86 & 8,86 & 8,58 & 12,24 & 13,96 & 15,3 & 21,18 & 24,24 \\
\hline 2 & 12 & 8,86 & 12 & 8,86 & 13,96 & 12 & 13,96 & 24,24 & 12 & 24,24 \\
\hline 3 & 16 & 8,86 & 16 & 8,86 & 13,96 & 16 & 13,96 & 24,24 & 16 & 24,24 \\
\hline 4 & 18 & 8,86 & 18 & 8,86 & 13,96 & 18 & 13,96 & 24,24 & 18 & 24,24 \\
\hline $\bar{x}$ & 13,5 & & 13,215 & & & 14,56 & & & 16,795 & \\
\hline$s_{x}$ & 4,43 & & 4,92 & & & 2,94 & & & 3,84 & \\
\hline$s_{x} / \bar{x}$ & 0,33 & & 0,37 & & & 0,20 & & & 0,23 & \\
\hline$B W R^{0}$ & - & & 1,12 & & & 0,61 & & & $\mathbf{0 , 7 0}$ & \\
\hline$B W R^{-1}$ & - & & 1,12 & & & 0,54 & & & 1,15 & \\
\hline
\end{tabular}

Forrás: saját szerkesztés

Látható, hogy a rendelési mennyiségek, melyek az előre meghatározott volumenü záró készlet elérése érdekében lettek definiálva, az első periódus után normalizálódnak. A lánctagok képesek tartani a készletezési politika által elöírt zárókészlet mennyiségeket, így nincsenek nagy kilengések a rendelési mennyiségekben, a készleteket pedig a kívánt szinten képesek tartani. Nincsenek nagy kiugrások, nincsenek hatalmas készletmennyiségek, mégis képesek a felmerülő igényeket maradéktalanul kielégíteni. A BWR mutatószámok esetén is látható, hogy nincs egyértelmü növekedés, tehát az ostorcsapás-effektus nem állapítható meg jelen lánc és készletezési politika esetében. Ez azt jelenti, hogy ha még egyértelmüen nem sikerült teljes mértékben kizárni az effektust, csökkenteni, sőt minimalizálni lehetett annak hatásait. 
Az alkalmazott változtatásoknak köszönhetően a 4. ábrán szereplő rendelési mennyiségek érhetők el, melyek görbéi a vevői igényt csak kicsi kilengésekkel követik, valamint a 3. ábrán szereplő hatalmas kilengések jelen esetben teljesen megszünnek, a második periódustól kezdve pedig teljes harmóniában követik a lánctagok rendelései a valós vevői igényt.

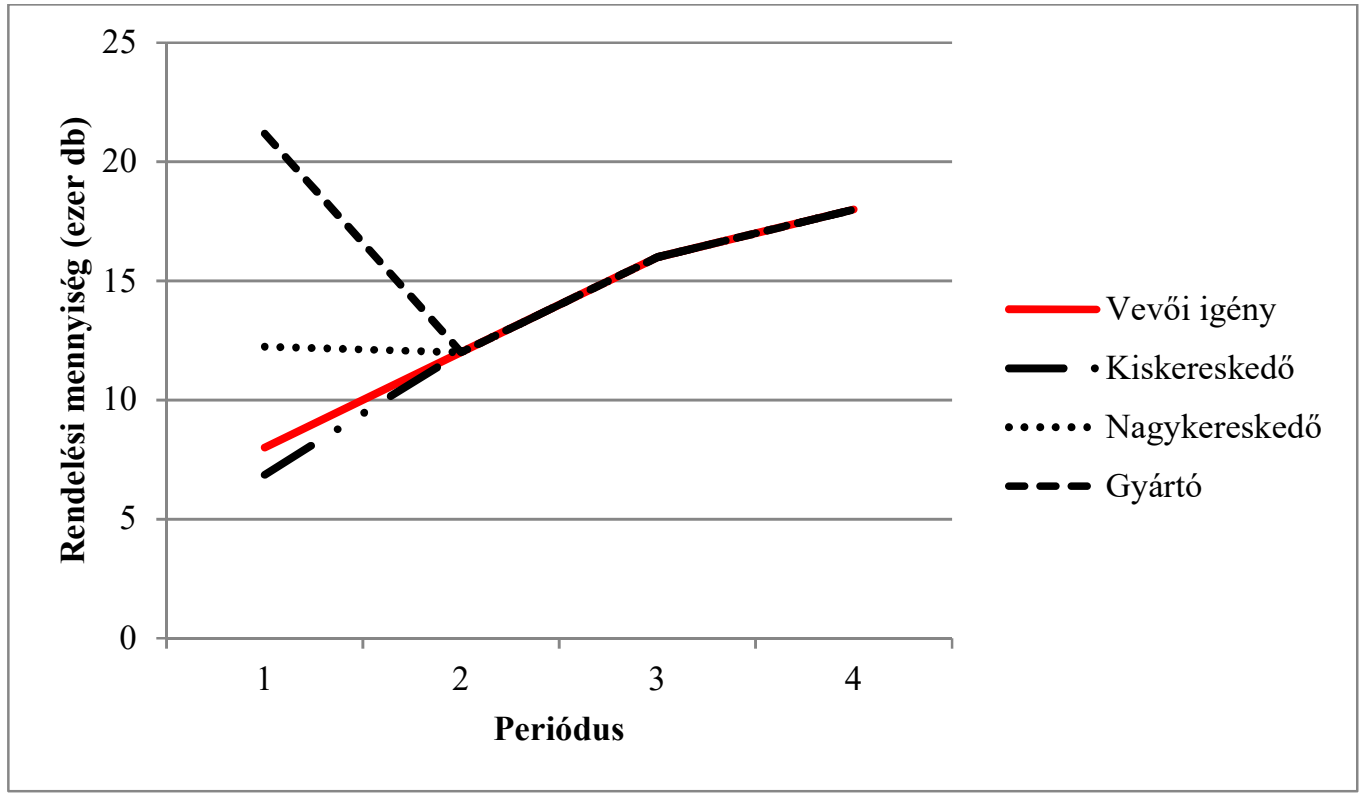

\section{4. ábra: Az ostorcsapás-effektus csökkentésének hatása az ellátási lánc rendelési mennyiségeire}

Figure 4: The effect of reducing the whiplash effect on supply chain order quantities Forrás: saját szerkesztés

Amennyiben sikeresen alkalmazza a vállalat a bemutatott menedzsment eszközöket, a 4. ábrához hasonló rendelési mennyiségek kalkulálhatók, melyek mellett biztosítható a költséghatékony müködés, a vevői kiszolgálási színvonal magas szinten tartása, valamint egy hosszútávú, minden fél számára kedvező feltételekkel rendelkező partnerkapcsolat, melyet nem, vagy csak minimálisan sújt az ostorcsapás-effektus.

\section{Összegzés}

Az ostorcsapás-effektus a XXI. század kiterjedt ellátási láncainak müködését nagymértékben megnehezítő jelensége. Készletezési zavarokat okoz, megnövelheti a költségeket, csökkentheti a vevő kiszolgálásának színvonalát, mely szintén veszteségeket okozhat a cégeknek. Ezért nagyon fontos, hogy a vállalatok, pontosabban azok ellátásilánc-menedzsmentje foglalkozzon az ostorcsapás mérésével, illetve hatásainak minimalizálásával vagy eliminálásával.

Az ostorcsapás-effektus méröszáma a BWR mutatószám, mely alkalmazható a teljes lánc vizsgálatára. Ebben az esetben a vevői igényekhez képest kell vizsgálni az egyes lánctagok rendelési mennyiségeit. Amennyiben ez az érték monoton növekszik, az azt jelenti, hogy az ostorcsapás-effektus jelen van az adott láncon belül. A BWR mutatószám alkalmas még a láncon egymás mellett álló partnerek igényeinek analizálására is. Ebben az esetben megállapítható, hogy a lánctagok mennyire ismerik és követik a partnereik szükségleteit.

Az előző fejezetben bemutatott 4. ábra egy ideális esetet mutat, amikor a vevői igények pontosan előrejelezhetők, mert minden szükséges információ a rendelkezésre áll. Az egyes 
lánctagok igényei követik a vevői igény trendjét, illetve a közvetlen partner szükségleteihez is illeszkednek nagyobb kilengés jelenléte nélkül. Ahhoz, hogy ez az állapot elérhető legyen, a vállalatok attitüdjeinek megváltozására van szükség. Elsősorban meg kell alapozni a bizalmon alapuló kapcsolatot. Ezt úgy lehet elérni, ha közös célokat határoznak meg, esetleg erőforrásaik egy részét is hajlandóak megosztani egymással a hatékony és eredményes müködés érdekében. Tehát valamilyen kölcsönösen előnyös, együttmüködésen alapuló stratégiai szövetséget érdemes kötni és ezt a müködési formát érdemes valamilyen szerződéssel megerősíteni, illetve irányítani, mely segít meghatározni, hogy milyen mértékben kerüljenek megosztásra a költségeket és nyereségeket. Ekkor olyan aktuális, illetve múltbéli keresleti információk is megosztásra kerülnek, melyhez alapesetben nem férnének hozzá a partnerek. Ezek az információk pedig segítik a pontosabb elörejelzések elkészítését, hiszen a múlt trendjeinek követése segítségével következtetések vonhatók le a jövővel kapcsolatban. Ezek azonban megkövetelik a fejlett, korszerü informatikai hátteret, mely nélkül nem lehetne alkalmazni a XXI. században már elengedhetetlen, modern IT eszközöket.

Tehát a különböző menedzsment eszközök együttes alkalmazása, mint a stratégiai menedzsment, a kapcsolatmenedzsment vagy a keresletmenedzsment, erösíti az optimális müködési feltételek létrejöttét, ugyanakkor gyengíti az ostorcsapás-effektus hatásait.

\section{Köszönetnyilvánítás}

A cikkben/elöadásban/tanulmányban ismertetett kutató munka az EFOP-3.6.1-16-2016-00011 jelu „Fiatalodó és Megújuló Egyetem - Innovatív Tudásváros - a Miskolci Egyetem intelligens szakosodást szolgáló intézményi fejlesztése” projekt részeként - a Széchenyi 2020 keretében - az Európai Unió támogatásával, az Európai Szociális Alap társfinanszirozásával valósul meg.

\section{Irodalomjegyzék}

ALTUG, M., S, - RYZIN, G., V. (2014): Is Revenue Sharing Right for Your Supply Chain? California Management Review, Vol. 56. No. 4., pp. 53-81. https://doi.org/10.1525/cmr.2014.56.4.53

CHEN, F. - DREZNER, Z. - RYAN, J. K. - SIMCHI-LEVI, D. (2000): Quantifying the bullwhip effect in a simple supply chain: The impact of forecasting, lead times, and information. Management Science, Vol. 46, No. 3, pp. 436-443. DOI: 10.1287/mnsc.46.3.436.12069

COLTMAN, T. - BRU, K. - PERM-AJCHARIYAWONG, N. - DEVINNEY, T. M. - BENITO, G. R. (2009): Supply Chain Contract Evolution. European Management Journal, Vol. 27, Issue 6, pp. 388-401. https://doi.org/10.1016/j.emj.2008.11.005

COSTANTINO, F. - DI GRAVIO, G. - SHABAN, A. - TRONCI, M. (2013): Exploring the Bullwhip Effect and Inventory Stability in a Seasonal Supply Chain. International Journal of Engineering Business Management 5, 10.5772/56833, online elérhetöség: https://journals.sagepub.com/doi/epub/10.5772/56833 (letöltve: 2020. 11. 02.), DOI: $10.5772 / 56833$

GUPTA, D. - WEERAWAT, W. (2006): Supplier-manufacturer coordination in capacitated twostage supply chains. European Journal of Operational Research, Vol. 175., Issue 1., pp. 67-89. DOI: 10.1016/j.ejor.2005.04.021

HILL, C. A. - ZHANG, G. P. - MILLER, K. E. (2018): Collaborative planning, forecasting, and replenishment - firm performance: An empirical evaluation. International Journal of Production Economics, Vol. 196, pp. 12-23. DOI: 10.1016/j.ijpe.2017.11.012

KAIPIA, R (2007): Supply Chain Coordination - Studies on planning and information sharing mechanisms. Helsinki University of Technology Laboratory of Industrial Management Doctoral dissertation series 2007 / 2, Espoo 
MENTZER, J., T. - DEWITT, W. - KEEBLER, J., S. - MIN, S. - NIX, N., W. - SMITH, C., D. ZACHARIA, Z. G. (2001): Defining Supply Chain Management. Journal of Business Logistics, Vol. 22., No. 2., pp. 1-25.

NAGY, J. - BÓDI-SCHUBERT, A. (2014): Keresletmenedzsment. In: Termelés, szolgáltatás, logisztika - Az értékteremtés folyamatai (szerk.: Demeter Krisztina), Complex, Budapest

POLO, M. - SCARPA, C. (2013): Liberalizing the gas industry: Take-or-pay contracts, retail competition and wholesale trade. International Journal of Industrial Organization 31, pp. 64-82. DOI: 10.1016/j.ijindorg.2012.10.003

PRAKASH, O. - PANDEY, V. (2014): Reducing the Bullwhip Effect in a Supply Chain Using Artifical Intelligence Technique. Journal of Production Research - Management, Vol. 4, Issue 2, pp. 31-42.

SZEGEDI, Z. (2017): Ellátásilánc-menedzsment, Kossuth Kiadó, Budapest 